\title{
Labour Migrants During the Pandemic: A Comparative Perspective
}

\section{Arjan de Haan ${ }^{1}$}

Accepted: 2 September 2020 / Published online: 19 October 2020

(c) Indian Society of Labour Economics 2020

\begin{abstract}
The COVID-19 pandemic and the accompanying policies of confinement or lockdown have been amply demonstrated and are possibly reinforcing economic, social and gender inequalities. Because of the nature of the measures that governments took in response to the health crisis, migrants-including the millions of labour migrants in Indian cities-have been placed in a particularly vulnerable situation. This essay provides a comparative and historical perspective of the conditions of migrant workers, arguing that the disadvantages migrants face are entrenched in economic and social structures, unearthed in this pandemic, and that alongside immediate social protection measures, policies need to address the deep-rooted barriers that keep migrants vulnerable.
\end{abstract}

Keywords Labour migrants · Circular migration · Inequalities · COVID-19 · Inclusive policies

\section{Introduction}

The COVID-19 pandemic and the accompanying policies of confinement or lockdown have been amply demonstrated and are likely reinforcing inequalities. Economic inequalities are reinforced as the better-off are better able to protect themselves, either secure in their jobs, or by having the resources to support themselves during a downturn. Gender inequalities are reinforced as women tend to be in more vulnerable jobs and are exposed to health risks. Social and identity (race, caste, nationality) inequalities often intersect with socio-economic inequalities.

This is written in personal capacity and does not represent the view of IDRC nor its Board of Governors.

Arjan de Haan

adehaan@idrc.ca

1 International Development Research Centre (IDRC), Ottawa, Canada 
Because of the nature of the measures governments around the world took in response to the health crisis, mobile populations have been placed in particularly vulnerable situations. Across the world, refugees are amongst the most vulnerable, their living conditions make containing the virus extra challenging, and stigmatisation likely increases. Labour migrants, similarly, often have poor living and working conditions, are exposed to health risks at work, have no social security or insurance to fall back on, and are often stigmatised.

Labour migrants' vulnerability manifested itself in extreme ways in India, when the government announced a lockdown, and big cities' labour migrants found themselves in the void of having lost their job, sometimes their housing, and in large numbers of cases having lost their income, and therefore with no alternative but to return to their home villages. Their plight has been well described in the media, by civil society organizations filling the gaps government agencies should be playing, and the efforts of groups of researchers.

This essay provides a comparative perspective of the conditions of migrant workers. ${ }^{1}$ I will summarise international experience-documented through investigative journalism and rapid research - that shows the vulnerability of migrants and gaps in policy frameworks globally. Further, it is important to understand how the conditions that migrants in India live in are not of recent origin, and the result of a structural condition of continued circulation between home villages that do not provide the necessary livelihoods and cities that need migrants but do not create the conditions for them to settle - they remain, as I slightly awkwardly called them in my publication on migrant workers in Calcutta 'unsettled settlers' (de Haan 1994).

This essay illustrates this with a comparison with other crises, including the economic crisis following 1929 where migrant workers disappeared like 'snow for the sun' (but without the health consequences migrants now are facing). I will argue that both research and theories, and policies have had a deep tendency to ignore and neglect the existence of this mobile population (de Haan 1999): both, for different reasons, have a deep sedentary bias. Academic studies have continued to see migration as a transitory phenomenon, often in line with what is seen as a classic process of industrialisation that England experienced. For policymakers, migration has remained largely invisible: data capture circulatory migration very poorly, rural development policies often have the aim to reduce migration, and-perhaps most important—-many of the public policies tend to be residence-based.

This perspective is offered to contribute to consideration of policies, particularly post-pandemic. If indeed the neglect of migrants is of a systemic nature, policy reforms need to address the roots of these. It would require a rethink of the place migrants play in India's society, to ensure data fully acknowledge the complex but sustained patterns of mobility that exist and to enquire how public policies need to be rebuilt on the basis of that reality.

\footnotetext{
1 The essay draws liberally on a range of sources, including investigative journalism and rapid research during the pandemic, peer-reviewed studies and my own earlier field research, and was written at a time that the daily numbers of infections in India are still increasing.
} 


\section{Inequalities Magnified: A Global Perspective}

As the COVOD-19 pandemic started to evolve, there was an initial impression that the virus was an 'equaliser'. Originating in Wuhan, China, its global spread affected global travellers and heavily impacted relatively affluent areas in Europe and the USA. Unprecedented policy responses were put in place that brought the spread of the virus under control in most OECD countries, while it continued to expand globally, including in India. ${ }^{2}$

But thoughts of the virus being the 'great equaliser', as the New York governor Cuomo, for example, called it, have rapidly dissipated. In the USA, '[1] ong-standing systemic health and social inequities have put some members of racial and ethnic minority groups at increased risk of getting COVID-19 or experiencing severe illness, regardless of age' (CDC 2020). In Ontario, Canada, '[s]ocial determinants of health ... such as gender, socio-economic position, race/ethnicity, occupation, Indigeneity, homelessness and incarceration, play an important role in risk of COVID19 infection, particularly when they limit ability to maintain physical distancing' (Public Health Ontario 2020). In Toronto, racialized people accounted for 83 per cent of COVID-19 cases, despite forming only 52 per cent of the population. ${ }^{3}$ Geographically, while the pandemic initially spread in nations' urban and well-connected centres, it has continued to spread to geographically more remote places and, particularly in developing countries, to areas with weak health sector capacities (and possibly also higher under-reporting).

The links between inequalities and the impact of COVID-19 run in both directions (Sachs 2020). Higher inequality tends to be associated with worse overall health conditions, increasing vulnerability to COVID-19 deaths. Inequalities can be associated with lower social cohesion and trust, and political polarisation, which can reduce governments' capacities to adopt measures needed to address the pandemic. Inequalities in the world of work - often associated with social identity, as discussed by Deshpande and Ramachandran (2020) for India-enhance the vulnerability of large numbers of workers. Manual workers, and owners of small businesses, are more likely to lose jobs or working hours, and thus income, and often have limited social security. Informal sector workers and women disproportionally are particularly vulnerable (WIEGO 2020). Those staying in work without being able to distance are exposed to infections: front-line health workers, domestic workers (GlobalVoices 2020), workers in food industries, vendors, and in tourism (Dempster and Zimmer 2020), with social and gender disadvantages usually compounding labour market ones.

\footnotetext{
${ }^{2}$ At the time of finishing the draft of this article, at the end of August 2020 the number of daily new cases in India had become larger than anywhere else in the world (Drèze 2020); the number of cases (and recorded deaths) relative to the population has remained well below the world's average (https://www. worldometers.info/coronavirus/; accessed 30 August 2020).

${ }^{3}$ Toronto Public Health data, between mid-May and mid-July, quoted in the Globe and Mail, July 30, 2020.
} 
Labour migrants face a multitude of disadvantages during the pandemic, which in turn may contribute to spreading the pandemic. ${ }^{4}$ First, the movement essential for their livelihoods in itself can pose a risk in terms of spread of infectious diseases, even if the initial COVID-19 spread did not primarily affect labour migrants. ${ }^{5}$ Many were stranded as economic activities and travel shut down, and international labour migrants were hit by the restrictions government around the world put in place. ${ }^{6}$ The restrictions in many cases have enhanced risks particularly for vulnerable groups including children (UNICEF 2020). There have been reports about mistreatment by smugglers (Rodriguez 2020). In the case of China, job loss as a result of the pandemic reinforced pre-existing inequalities along the household registration system (Che et al. 2020).

Second, the type of work migrants typically engage in, and their living conditions, makes them relatively vulnerable. The places migrants return to typically are under-served by health services. Absence of social protection measures makes it less easy for them to implement social distancing. As described by Choudhari (2020), mental health challenges may compound these disadvantages. Investigative journalism shows that migrant farm workers in Canada's agricultural sector are vulnerable to, and unprotected against the consequences of the pandemic (CBC 2020; Financial Post 2020), with migration status potentially limiting access to health care (Doyle 2020).

Third, the pandemic can reinforce stigma, both in host locations and when migrants return (for fear of carriers of diseases), and surveillance (Castillo 2020). There are reports from across the word of new or intensified discriminatory treatment, ${ }^{7}$ non-payment, for example, for domestic workers that stayed in their job (GlobalVoices 2020) and xenophobia (Douglas et al. 2020; IOM 2020b) (Douglas et al. 2020), for example, in varying contexts of Gulf States (Migrants-rights.org 2020), Canada (Hennebry et al. 2020), India (Ramasubramanyam 2020; Bajoria 2020), vis-à-vis African students in China (BBC 2020), and in Pakistan directed at Shia minorities (Mirza 2020).

\footnotetext{
${ }^{4}$ See for overviews by the World Bank (2020b), and guidance from the United Nations Human Rights Office of the High Commissioner (2020). On the impact of refugees, see, for example, Dempster et al. (2020), ILO (2020a).

${ }^{5}$ There is some information about the extent to which the migrants' exodus from Indian cities: a study by Aajeevika Bureau showed that none of the migrants that returned to Rajasthan in the first phase of lockdown in March were infected, and that there were cases of infections amongst migrants returning in May (SciDev.Net 2020).

${ }^{6}$ IOM 2020a. Estimates in West Africa indicated that regional migration decreased by 50 per cent (IOM 2020c).

${ }^{7}$ OHCHR (2020); extreme conditions for African labour migrants in Saudi Arabia were reported by Brown and Zelalem (2020).
} 


\section{Labour Migrants in India}

The vulnerability of labour migrants manifested itself in extreme ways in India, with disadvantages of work, identity and migratory status reinforcing each other. ${ }^{8}$ Their plight has been well described in media, by civil society organizations and researchers like the Stranded Workers Action Network (SWAN 2020a, b, c). When the government announced the lockdown, labour migrants in cities found themselves in the void of having lost their job, sometimes their housing, and in large numbers of cases their income. Many of them had no alternative but to return to their home villages, ${ }^{9}$ and as transport was cancelled as part of the lockdown, often on foot, exposed to hunger, and risks of infection, harassment, and poor conditions of forced quarantine. Migrant workers that stayed in cities often found working conditions worsen. ${ }^{10}$ Many migrants who had returned feel forced to return to cities as they run out of savings (Patnaik 2020).

As far as I am aware, there are no reliable numbers of the labour migrants that moved back, though there are some estimates of how many people moved by train: estimates have varied between 5 and 40 million. In fact, numbers of internal migrants generally are uncertain (Srivastava and Sutradhar 2016; Srivastava 2020a; GoI 2017), with the Inter-State Migrant Workmen Act of 1979 remaining to a great extent a dysfunctional framework (Sivaram 2020). Estimates put total numbers of internal migrant workers at about 100 million (against a Census estimate of some 45 million inter- and intrastate migrant worker ${ }^{11}$ ), mostly originating from poorer districts of Uttar Pradesh, Bihar, Odisha, Rajasthan, etc., and a relatively small proportion of these workers being from Nepal and Bangladesh. In particular, estimates of, and knowledge about circular and seasonal migration have remained uncertain. ${ }^{12}$ Female labour migration also is likely under-recorded (Shanthi 2006), adding significantly to the overall gaps in knowledge on migration. Moreover, academic studies commonly underestimate the role of labour mobility. ${ }^{13}$ Theories and models of migration tend to neglect the complexity of patterns of mobility, again enhancing the gaps in knowledge about the extent and impact of population mobility, often particularly important with respect to more marginalised groups.

\footnotetext{
8 https://rive.google.com/file/d/1glhO8wJrzLClRytfIzvV98wYqf7anS5s/view.

9 For Bihar, see, for example, Priyadarshini and Chaudhury (2020), in the edited volume on the migrant crisis by Ranabir Samaddar.

10 Sood and Nath (2020), Thomas and Jayaram (2020) and Mander and Verma (2020). Bailwal and Sah (2020) describe the conditions of some workers that stayed behind including increases in working hours, and the reasons for doing so (lack of work in home villages, outstanding payments from contractors).

11 https://censusindia.gov.in/2011census/d-series/d-3.html; in total, the Census 2011 enumerated 456 million people as migrants, with 211 million of them (mostly women) having moved for marriage.

12 Deshingkar et al (2008a). Similarly, estimates of remittances by internal migrants are uncertain (Export-Import Bank of India 2016).

13 For example, in Munshi and Rosenzweig (2009, 2020); see Deshingkar (2017). I believe that expectations of rates of urbanisation and observations that rates remain low (e.g. World Bank 2015, which refers to India's 'messy urbanization') have typically neglected the importance of circular migration (see Lucci 2016 for discussion on similar gaps in Africa).
} 
The lack of clear data appears to reflect, and possibly reinforces, the ambivalent treatment of migrants in official discourse (Deshingkar 2017). As in other countries, such as China during its years of miracle economic growth and institutionalised in its hukou system, and mirroring ambivalent views globally about the place of immigrant, migrants and labour mobility in particular have never been fully accepted as part of India's policy. Urban policies demonstrate common apathy and often discrimination towards migrants. ${ }^{14}$ Inter-state migrants are at risk of losing access to public social provisions, such as PDS, and even health care that are tied to permanent residence, and often do not have access to housing schemes in cities.

The apathy towards labour migration is often reflected in rural policies as well, with a common focus on reducing migration in development and anti-poverty programs (and in much international development policy). ${ }^{15}$ NREGA's objectives include reducing labour migration through the provision of locally available work in rural areas, similar to the earlier Maharashtra employment scheme (Datta 2019: 39-40; Solinski 2012).

\section{Mobility Neglected: An Historical Perspective}

The stories of migrants moving back to their villages of origin have parallels in earlier crises. Like the COVID-19 pandemic, the bubonic plague in 1994 led to largescale departure of migrants (though without them being stranded, as trains were made available), skilled and manual workers, from Surat, leading to a labour shortage when factories reopened.

Economic downturns have had similar impacts on migrant workers. In Calcutta's jute industry, in 1931 following the 1929 economic crisis, many jobs were cut (de Haan 1994). As the British colonial Labour Commissioner R. N. Gilchrist (1932) wrote, workers moved back to the rural areas en masse, without signs of protest: they disappeared as 'snow for the sun'. As during the 2020 pandemic, the timing and season of the return was significant, as the return happened during the month that workers usually would return for their annual visit to their homes (see further discussion below).

As in 2020, in 1931 the return of workers to their 'native villages' did not come as a surprise. In fact, it was a common occurrence, as patterns of migration wereand have continued to be-circular. Earlier long-distance migration streams, during the eighteenth and nineteenth centuries-for example from parts of Bihar to Rangpur, Mymensingh and the Sunderbans in eastern Bengal, and Burma, for agricultural and other manual work, including for railway construction (Yang 1989)—tended to be circular, as occupations were seasonal and temporary. This circular pattern continued to predominate for industrial labour: while industrial work such as in the

\footnotetext{
14 See Aggarwal et al. (2019); the index shows varying degrees of support for migration in India's states.

15 In international debates, there has been a growth appreciation of international migration and remittances, but with a continuously strong policy strand that sees development as a way to reduce (international) migration; see Clemens (2020) for a rebuttal of that view, in a context of continued debate.
} 
jute industry was much more continuous, many of the workers continued to remain migrants, maintaining close links with their villages of origin.

This predominance of circular (rural-to-urban) migration has been subject to a range of interpretations that often defined the phenomenon as an exception. On the one hand, colonial authorities and factory management attributed the pattern to workers' unwillingness to settle, and lack of commitment to modern industries, with high rates of labour turnover. They noted labour shortages, particularly during summer months, the time of harvest and or marriages. This was often highlighted as requiring informal middlemen ('sardars') for recruitment of workers and a common system of replacement ('badli') workers. The personalistic and informal nature of recruitment was closely associated with a segmentation of migration streams, a pattern that has continued to define India's labour market and migration. ${ }^{16}$

Critical studies, on the other hand, including the work by Breman (1985, 2019; see also his contribution to this volume) that have highlighted extreme exploitation in migrant work have argued that it was in the interest of capitalism to keep the workforce migratory, constituting a near-endless labour surplus (partly caused by the destruction of traditional artisanal production under colonialism), that employers and authorities did not invest in the living conditions that would allow workers and their families to settle, ${ }^{17}$ and that informal and segmented recruitment helped keep costs of labour low. During strikes or lockouts, also, workers would often return home; many trade union organisers in the jute industry shared the concerns of the employers about the lack of commitment of the migrant worker to the industry and urban area. ${ }^{18}$

Most of India's migrant labourers have been men, and this too has been explained either by reference to workers traditional customs or preferences, or managers' strategies and their lack of investment in living conditions surrounding factories. In my own view, single-factor explanations are insufficient to explain the diversity of migration patterns within one industry or area of destination, nor the historical trends towards a single male earner. ${ }^{19}$

Explanations for this pattern of rural-urban migration, in my view, need to take into account the complexity of interaction between rural and urban societies, contrasting the 'classic' historical interpretation of the formation of an industrial and urban working class (de Haan and Rogaly 2002). Availability of seasonal work, of course, provides temporary opportunities outside villages that themselves provide insufficient employment. But even when work was more permanent, migrants have continued to maintain a link with their villages. ${ }^{20}$

\footnotetext{
16 Described, for example, by Subramaniam (2018) for tea sellers in Mumbai.

17 See, for example, the collection by Samaddar (2016) for a set of recent studies on workers in Indian cities.

18 On continued constraints for union organisation caused by circular migration, see Ghosh and Bandyopadhyay (2020), Menon (2020).

19 The pattern of migration varied across regional and perhaps religious communities; but across communities, female migration did occur (de Haan 1994; Fernandes 1997; Sen 1992).

20 This has remained the case of international migrants as well, described, for example, for migrants from Punjan, and by Gardner (1995) for Sylhet, Bangladesh; see also Gardner and Osella (2003).
} 
The importance of this continued pattern was clearly expressed in the words of the industrial workers in the jute industry I interviewed. 'What to do? My house is there!'. Many said that they go when there was a 'need' or 'work': marriage, an emergency, taking care of the land, settling land disputes, education of the children, or simply visiting family was a key reason for going to the village, for 1 or 2 months per year, quite often longer and frequently beyond the allowed period of leave.

From the perspective of rural development, similarly, it is critical to take into account this continued interaction of rural and urban economic activity. Research on out-migration from Bihar ${ }^{21}$ shows the long history of out-migration, as well as the fact that this has involved most socio-economic strata, including, for example, sons of larger landowners (as described by Das 1986). From a functionalist perspective, this continued out-migration, while caused by poverty in many parts of Bihar, also helped to maintain its socio-economic structure, with remittances supporting the structure of landownership. Unlike for international migrants-who typically have come from less poor areas in India-the income from rural-urban unskilled labour migration generally did not allow for significant investment in agricultural or other rural production, but functioned as a safety valve, economically as well as socially.

This rural-urban interaction has by and large remained outside the view of development strategies, possibly regarded as merely a transitional or exceptional phenomenon. It is not well reflected in census or surveys, which have underestimated degrees of labour migration and its importance for development in both urban and rural areas. Policies have remained by and large silent and in neglect of this reality, or indeed — as mentioned above—have aimed to reduce that mobility.

It is important to reiterate that this neglect impacts different groups of migrants differently and that it is migrants in the informal sector that are particularly affected. It appears that the neglect of migrants' conditions - under the pandemic and long term-is mirrored in a neglect of the so-called informal sector. As much as circular migration has remained a feature of India's modernising economy, the size of the informal sector has remained the same, and policies to address these ineffective or absent.

The long-standing neglect of migration has contributed to policy gaps that so clearly surfaced with the COVID-19 lockdown. International reporting has suggested that the extent of suffering for migrant workers seemed to be particularly extensive in India. The pattern of circular migration that has contributed to the sudden large-scale movement is not unique to India; for example, similar movements of annual return are witnessed during China's New Year, and there have been reports from West African cities of young migrants moving back to their villages to support harvesting. What appears pronounced is the neglect and negligence by official policy and employers: while public health concerns of course directed a cessation of movement, there were no or very limited attempt to safeguard the travel of those tens of millions of workers.

${ }^{21}$ Sources cited there. 


\section{Inclusive Policies}

It is important to highlight the initiatives that supported migrant workers in India, including civil society efforts (such as SWAN mentioned above and SEWA as described in Homenet 2020), Self Help Group initiatives (IFAD 2020), and Central Government support measures. ${ }^{22}$ Bihar's Chief Minister offered to cover the costs of stranded migrant workers elsewhere in India. Odisha's Chief Minister offered to bring back migrants that were stuck in different parts of the country during lockdown; the government set up dedicated hospitals and health centres and announced a package of income and employment support for returning workers (Mishra 2020; The Indian Express 2020).

Kerala that stood out for its proactive response to the emerging COVID-19 pandemic provided support to migrant workers that had lost employment (The Week 2020; The Economic Times 2020). It set up camps using, for example, schools and provided basic necessities and health-related information in various languages. Kerala's response may have led to a relatively small proportion of migrant workers returning to their villages of origin (Nideesh 2020).

While these responses do play a role and have provided essential support to migrants, they are insufficient to address major inequalities and the risks associated with health and other shocks. The disadvantages migrants face-unearthed in this pandemic - are entrenched in economic and social structures. How can this be turned around? What policies are needed to address the deep-rooted barriers that keep migrants vulnerable? And does the current crisis provide an opportunity for such changes?

Critical, in my view, is the need to accept migration, and the specific patterns of migration and the contribution migrant workers make to local economies. Often, there is a greater - and important - concern for the well-being of migrants abroad, ${ }^{23}$ and it is important that the vulnerability of internal migrants is equally recognised. With the benefit of hindsight, the way the Government was caught by surprise by the chaos caused by the lockdown — and the public health risks this may have causedis part of a pattern of neglect of labour migration. Despite their essential function in the urban economy (and possible costs to the economy of labour shortages workers have left), seasonal and circular migrant workers do not have a fixed or accepted place in cities (Kundu 2009), with as mentioned many of their entitlements based in their villages of origin. Accounting for these migration patterns, and their impacts

\footnotetext{
22 See Srivastava (2020a: pp. 15-22), describing these as inadequate. The GoI (GoI 2017) working group describes a range of needed long-term measures. Following the crisis, the Central government increased support to MNREGA and food subsidies (the latter to 800 million people); The Wire (30 June 2020); Livelaw News Network (2020). In Rajasthan, the demand for work in MNREGA increased by some 20 per cent during April-July compared to the sae period in the previous year (Kumar 2020).

23 The international community too tend to prioritise attention to international migrants (and remittances), despite the much larger numbers of internal migrants (see, for example, World Bank 2020a or https://migrationdataportal.org/themes/migration-data-relevant-covid-19-pandemic that focuses on international migration while using the generic term migration).
} 
on household forms, in surveys (for example in the form of Kerala's migration survey) and census is a critical first step.

A 'regularisation' of migrant workers ensures all citizens can access rights and entitlements independent of their current residence. ${ }^{24}$ During the crisis, some countries and authorities limited the rights of migrants ${ }^{25}$ while others enhanced these. Bahrain declared an amnesty during 2020 for irregular workers in the country to get regularized without paying any fees or fines (Sorkar 2020). On the sending side, countries like Bangladesh that for many years have institutionalised support to international migrants—often supported by IOM—put in place schemes for returning workers including soft loans for training and starting economic activities (Sorkar 2020). The Philippines' government in collaboration with non-state actors has been commended for its proactive role in repatriating, and welfare measures for migrants (albeit with significant gaps in implementation; Liao 2020).

Ensuring migrants have access to their right requires a range of reforms and new measures, most of which are not new. ${ }^{26}$ Social protection measures need to become 'portable' (Srivastava 2020b); subsidised food, for example, needs to be accessible independent of location. The 'one nation one ration card' initiative could be a critical step towards this goal, and there is a need and opportunity to apply existing technology to enable easier transfers of financial support (Shreedharan and Jose 2020). Where migrants move with families including children, education (CREATE 2008) and mid-day meals need to be accessible-similar to education initiatives under Sarva Shiksha Abhiyan and the District Primary Education Programme (Majumder 2011) - to them. Registration for welfare provisions needs to be simple.

Migrants should be able to avail the same political rights NRI's have been given, to vote by ballot (Ghosh and Bandyopadhyay (2020); recent analysis by Gaikwand and Nellis (2020) shows low political participation by migrants, and hence a lower likelihood that politicians represent their interests. Health services-regular care as well as pandemic services-need to be accessible to migrants as much as local populations (Kusuma and Babu 2018; Nitika et al. 2014). Sustained advocacy for workers rights, such as by Aajeevika, SEWA, ${ }^{27}$ and more recently new networks as mentioned above, as well as effective representation by trade unions is an essential element of ensuring migrants can realise their rights.

\footnotetext{
${ }^{24}$ The idea of regularisation during crisis was put forward by the UN (2020) and derives partly from efforts in Europe, Portugal and Italy in particular, providing, for example, health care to undocumented migrants, in fact implementing long-standing European commitments (Fanjul and Dempster (2020).

25 As widely described (e.g. Pierce and Bolter 2020), the US administration moved forward its policy reforms started in 2017 during the pandemic.

${ }^{26}$ See, for example, Deshingkar et al (2008a) for India; Leighton (undated) and UNHCR (undated) for international migrants, and Solomon and Sheldon (2018) on the Global Compact. See ILO (2020b) for a discussion on social protection for migrants workers

${ }^{27}$ See the description—based on a rapid survey—of the role (including advocacy) of membership-based organizations of care workers, home-based workers, etc., during the pandemic in WIEGO (2020: 22); also Sinha (2020).
} 


\section{Conclusion}

The marginalisation of migrant workers in India is deep-rooted, has a long historical background and continuity since the colonial period, and manifests itself in the absence of knowledge and data of how many migrant workers live and work outside their place of residence. Urban authorities and employers have continued to take the pattern of circular migration for granted, providing minimal facilities and security for its workers, reinforcing a lack of belonging and ability for migrants to settle with their families.

The unique shock that COVID-19 implied, but equally importantly the government's response, lockdown and extremely limited support for the tens of millions of migrant workers, showed how deep this neglect is, and the potential costs for the migrants themselves but also the health system and the economy more broadly. Crises provide opportunities for 'building back better': in the case of migrant workers these consist of essential immediate social protection, but also, and likely much more challenging, addressing deep-rooted inequalities that keep workers in marginalized positions, and the invisibility of the migrants that once again were absorbed by their villages of origin.

This case of neglect of migrant workers during the pandemic in India was quite widely reported, at least during the early months of the pandemic. The rapid survey of sources on which this essay is built suggest that there has been much less reporting in other parts of the world; this may be a case of under-reporting, or an indication of particular and widespread vulnerability of migrants in India. Responses to shocks for international migrants have seen both new supportive measures, and further marginalisation and stigmatisation. It seems important to develop exploration of the varied responses and of the policies and advocacy that can address the deep-rooted disparities that migrant workers face.

\section{References}

Aggarwal, V. et al. 2019. How state governments disenfranchise interstate migrants in India. https ://www.indiaspend.com/how-state-governments-disenfranchise-interstate-migrants-in-india/. Accessed 23 August 2020.

Bailwal, N., and T. Sah. 2020 Travails and travesties: The plight of migrant workers who did not leave Delhi. https://thewire.in/rights/migrant-workers-delhi-lockdown-stayed. Accessed 23 August 2020.

Bajoria, J. 2020. CoronaJihad is only the latest manifestation: Islamophobia in India has been years in the making. https://www.hrw.org/news/2020/05/01/coronajihad-only-latest-manifestation-islamophob ia-india-has-been-years-making. Accessed 23 August 2020.

Breman, J. 1985. Of peasants, migrants and paupers: Rural labour circulation and capitalist production in West India. Oxford: Oxford University Press.

Breman, J. 2019. Capitalism, inequality and labour in India. Cambridge: Cambridge University Press.

Brown, W., and Z. Zelalem. 2020. Investigation; African migrants left to die in Saudi Arabia's hellish COVID detention centres. https://www.telegraph.co.uk/global-health/climate-and-people/investigat ion-african-migrants-left-die-saudi-arabias-hellish/. Accessed 31 August 2020.

BBC. 2020. Africans in China: we face coronavirus discrimination. https://www.bbc.com/news/world -africa-52309414. Accessed 18 August 2020. 
Castillo, R. 2020. How discrimination towards Africans and China's surveillance state will reset a migration trend. https:/qz.com/africa/1844277/racism-to-africans-in-china-and-surveillance-to-slowmigration/. Accessed 18 August 2020.

CBC. 2020. https://www.cbc.ca/news/canada/leamington-migrant-workers-1.5633032.

CDC. 2020. Health Equity Considerations and Racial and Ethnic Minority Group. https://www.cdc.gov/ coronavirus/2019-ncov/need-extra-precautions/racial-ethnic-minorities.html.

Che, L., H. Du, and K.W. Chan. 2020. Unequal pain: a sketch of the impact of the COVID-19 pandemic on migrants' employment in China. Eurasian Geography and Economics. https://doi. org/10.1080/15387216.2020.1791726.

Clemens, M. 2020. Emigration rises along with economic development: aid agencies should face this, but not fear it. https://www.cgdev.org/blog/emigration-rises-along-economic-development-aid-agenc ies-should-face-not-fear-it. Accessed 28 August 2020.

Dempster, H., and C. Zimmer. 2020. Migrant workers in the Tourism Industry: how has COVID-19 affected them, and what does the future hold?' https://www.cgdev.org/publication/migrant-worke rs-tourism-industry-how-has-covid-19-affected-them-and-what-does-future. Accessed 17 August 2020.

Dempster, H. et al. 2020. Locked down and left behind: the impact of COVID-19 on refugees' economic inclusion. https://www.cgdev.org/publication/locked-down-and-left-behind-impact-covid-19-refug ees-economic-inclusion. Accessed 17 August 2020.

Choudhari, R. 2020. COVID 19 pandemic: Mental health challenges of internal migrant workers of India', https://www.ncbi.nlm.nih.gov/pmc/articles/PMC7301775/. Accessed 17 August 2020.

CREATE. 2008. Distress seasonal migration and its impact on Children's Education, Create Pathways to Access Research Monograph No. 28 At www.create-rpc.org/pdf_documents/PTA28.pdf. Accessed 7 February 2012

Das, A. 1986. The 'Longue Duree': continuity and change in changel. Historiography of an Indian Village from the 18th towards the 21st Century, CASP 14, Rotterdam.

Datta, A. 2019. Continuity and Change: Migration and Development in India. The Case of Bihar. PhD thesis, International Institute for Social Studies, Erasmus University Rotterdam.

Deshingkar, P. 2017. Towards contextualised, disaggregated and intersectional understandings of migration in India. Asian Population Studies 13 (2): 119-123. https://doi.org/10.1080/17441 730.2016.1189655.

Deshingkar, P., P. Sharma, S. Kumar, S. Akter, and J. Farrington. 2008a. Circular migration in Madhya Pradesh: changing patterns and social protection needs. The European Journal of Development Research 20 (4): 612-628.

Deshingkar et al (2008b) Support for migrant workers: the missing link in India's development https:// www.odi.org/sites/odi.org.uk/files/odi-assets/publications-opinion-files/3343.pdf. Accessed 30 August 2020).

Deshpande, A., and R. Ramachandran. 2020. Is COVID-19 “The Great Leveler"? The Critical Role of Social Identity in Lockdown- induced Job Losses. Ashoka University Working Papers https://www. ashoka.edu.in/page/CEDA-working-papers-389. Accessed 16 August 2020.

Douglas et al. 2020. https://www.unicef.org/eap/press-releases/end-stigma-and-discrimination-againstmigrant-workers-and-their-childr'en-during.

Doyle, S. 2020. Migrant workers falling through crack in health coverage, https://www.cmaj.ca/conte nt/192/28/E819. Accessed 17 August 2020.

Drèze. J. 2020. India is in denial about the COVID-19 crisis. https://www.scientificamerican.com/article/ india-is-in-denial-about-the-covid-19-crisis/. Accessed 30 August 2020.

De Haan, A. 1994. Unsettled settlers: Migrant workers and industrial capitalism in Calcutta. de Haan, Hilversum: Verloren, Hilversum (and Calcutta: K.P. Bagchi, 1996).

De Haan, A. 1999. Livelihoods and poverty: The role of migration A. critical review of the migration literature. Journal of Development Studies 36 (2): 1-47.

de Haan, A., and B. Rogaly (eds.). 2002. Labour mobility and rural society. London: Frank Cass.

Export-Import Bank of India. 2016. Migration and Remittances in India. Occasional Paper No. 177. https ://www.eximbankindia.in/Assets/Dynamic/PDF/Publication-Resources/ResearchPapers/54file.pdf. Accessed 21 August 2020.

Fanjul, G., and H. Dempster. 2020. Regularizing migrant workers in response to COVID-19. https:// www.cgdev.org/blog/regularizing-migrant-workers-response-covid-19. Accessed 27 August 2020.

Fernandes, L. 1997. Producing workers: The politics of gender. Philadelphia: Class and Culture in the Calcutta Jute Mills. 
Financial Post. 2020. https://business.financialpost.com/news/migrant-workers-facing-unsafe-workingliving-conditions-report. Accessed 23 Sept 2020.

Gaikwand, N., and G. Nellis. 2020. Do politicians discriminate against internal migrants? Evidence from nationwide filed experiments in India. American Journal of Political Science. https://doi. org/10.1111/ajps.12548.

Gardner, Katy. 1995. Global migrants, local lives. Travel and transformation in Rural Bangladesh. Oxford: Clarendon Press.

Gardner, K., and F. Osella. 2003. Migration, modernity and social transformation in Asia: An overview. Contributions to Indian Sociology 37 (1\&2): 251-280.

Ghosh and Bandyopadhyay. 2020. Postal ballot voting rights: The only way migrant workers can make their presence felt. https://thewire.in/rights/postal-ballot-votes-migrant-workers. Accessed 24 August 2020.

Gilchrist, R.N. 1932. Indian labour and the land. Calcutta: West Bengal Government Press.

GlobalVoices. 2020. Invisible hands: How millions of domestic workers fare under COVID-19. https:// globalvoices.org/2020/07/20/invisible-hands-how-millions-of-domestic-workers-fare-under-covid $-19 /$. Accessed 30 August 2020.

GoI, Government of India. 2017. Report of the Working Group on Migration. Ministry of Housing and Poverty Alleviation. New Delhi. http://mohua.gov.in/upload/uploadfiles/files/1566.pdf. Accessed 16 August 2020.

Hennebry et al. 2020. https://theconversation.com/coronavirus-canada-stigmatizes-jeopardizes-essentialmigrant-workers-138879.

Homenet. 2020. Power in organising: How SEWA Delhi worked through riots and the COVID-19 pandemic to reach 47,000 women workers. https://hnsa.org.in/blog/power-organising-how-sewa-delhi -worked-through-riots-and-covid-19-pandemic-reach-47000-women. Accessed 30 August 2020.

IFAD. 2020. When they came home. Migration and responses to COVID-19 in India. https://www.ifad. org/en/web/latest/blog/asset/41903442. Accessed 21 August 2020.

ILO. 2020a. Protecting the rights of work of refugees and other forcibly displaced persons during the COVID-19 pandemic. https://www.ilo.org/global/topics/labour-migration/publications/ WCMS_748485/lang-en/index.htm. Accessed 17 August 2020.

ILO. 2020b. Social protection for migrant workers: A necessary response to the COVID-19 crisis. https ://www.ilo.org/secsoc/information-resources/publications-and-tools/Brochures/WCMS_748979/ lang-en/index.htm. Accessed 17 August 2020.

IOM. 2020a. International Organisation for Migration (2020). Journeys Interrupted' https://storytelle r.iom.int/stories/journeys-interrupted. Accessed 18 August 2020.

IOM. 2020b Countering xenophobia and stigma to foster social cohesion in the COVID 19 response and recovery. https://www.iom.int/sites/default/files/documents/countering_xenophobia_and_stigm a_130720.pdf. Accessed 18 August 2020.

IOM. 2020c. Migration flows across West and Central Africa nearly halved by COVID-19; moble populations economically impacted. https://www.un.org/africarenewal/news/coronavirus/migration-flows -across-west-and-central-africa-nearly-halved-covid-19-mobile-populations. Accessed 21 August 2020.

Kumar, R. 2020. Post-lockdown, workers demand more work, better wages under rural jobs scheme. IndiaSpend https://www.indiaspend.com/post-lockdown-workers-demand-more-work-better-wages -under-rural-jobs-scheme/. Accessed 23 August 2020.

Kundu, A. 2009. Exclusionary urbanisation in Asia: a macro overview. Economic and Political Weekly 1 (48): 48-58.

Kusuma, Y.S., and B.V. Babu. 2018. Migration and health: A systematic review on health and health care of internal migrants in India. The International Journal of Health Planning and Management, https ://onlinelibrary.wiley.com/doi/abs/10.1002/hpm.2570?casa_token=7zplRvizo6AAAAAA\%3ApwI 5TAztKRMD7xr2YE66S555J5Dy4z8QS8_kZJ5EmMnQW5cGZRA4A17bLkZbDcuihf8oTC u3kHIUU3U. Accessed 28 August 2020.

Leighton, M. undated. Labour migration and inclusive development setting a course for success https:// www.un.org/en/chronicle/article/labour-migration-and-inclusive-development-setting-course-succe ss. Accessed 30 August 2020.

Liao, K.A.S. 2020. Emergency returns: COVID-19 and the repatriation of Filipino migrant workers. https ://www.compas.ox.ac.uk/2020/emergency-returns-covid-19-and-the-repatriation-of-filipino-migra nt-workers/. Accessed 23 August 2020. 
Livelaw News Network. 16 July 2020. Plea in SC for extension of scheme for distribution of dry rations to Migrant Labourers Under Atma Nirbhar Bharat Scheme For 12 Months https://www.livelaw.in/ top-stories/plea-in-sc-for-extension-of-scheme-for-distribution-of-dry-rations-to-migrant-labou rers-under-atma-nirbhar-bharat-scheme-for-12-months-read-application-159995. Accessed 16 August 2020.

Lucci, P. et al. 2016. Sustainable cities: Internal migration, jobs and the 2030 sustainable development agenda. ODI Briefing, https://www.odi.org/publications/10576-sustainable-cities-internal-migra tion-jobs-and-2030-agenda-sustainable-development. Accessed 24 August 2020.

Majumder, R. 2011. Paternal migration, child labour and education: A study in brickfield areas in West Bengal. https://mpra.ub.uni-muenchen.de/40940/1/MPRA_paper_40940.pdf. Accessed 30 August 2020 .

Mander, H., and A. Verma. 2020. The Coronavirus lockdown has been a war on India's informal labour. The Wire https://thewire.in/labour/coronavirus-lockdown-informal-labour. Accessed 24 August 2020 .

Menon. 2020. https://www.thenewsminute.com/article/migrant-worker-crisis-why-trade-unions-are-missi ng-india-s-informal-sector-129131. Accessed 23 Sept 2020.

Migrants Rights. 2020. https://www.migrant-rights.org/2020/04/the-covid-19-crisis-is-fueling-more-racis t-discourse-towards-migrant-workers-in-the-gulf/. Accessed 23 Sept 2020.

Mirza, J.A. 2020. Pakistan's Hazara Shia minority blamed for spread of COVID-19. https://www.ids. ac.uk/opinions/pakistans-hazara-shia-minority-blamed-for-spread-of-covid-19/. Accessed 23 Sept 2020.

Mishra, A. 2020. As Odisha struggles to deal with raid COVID-19 spread, migrant workers demand more testing. https://thewire.in/government/odisha-covid-19-migrant-workers-testing. Accessed 30 August 2020.

Munshi, K., and Rosenzweig, M. 2009. Why is mobility in India so low? Social insurance, inequality, and growth. Www.stanford.edu/group/SITE/SITE_2009/segment_2/2009_s2_papers/rosenzwieg.pdf. Accessed December 2010.

Munshi, K., and Rosenzweig, 2020. Why is labor mobility in India so low. https://microeconomicinsight s.org/why-is-labor-mobility-in-india-so-low/. Accessed 28 July 2020.

Nideesh, M.K. 2020. Lockdown: at only 1.6\% return migration, Kerala holds clues to solve the problem. https://www.livemint.com/news/india/lockdown-at-only-1-6-return-migration-kerala-holds-clues -to-solve-the-problem-11589973133404.html. Accessed 30 August 2020.

Nitika, A.Y., B. Nongkynrih, and S.K. Gupta. 2014. Migrants to Urban India: Need for Public Health Action. Indian Journal of Community Medicine 39 (2): 73-75.

Patnaik, I. 2020. Why migrant workers are starting to return to cities and how this can revive economy faster https://theprint.in/ilanomics/why-migrant-workers-are-starting-to-return-to-cities-how-thiscan-revive-economy-faster/435923/.

Pierce, S. and J. Bolter (2020) 'Dismantling and reconstructing the US immigration system: A catalog of change under the Trump presidency' https://www.migrationpolicy.org/research/us-immigratio n-system-changes-trump-presidency. Accessed 17 August 2020.

Priyadarshini, A., and S. Chaudhury. 2020. The return of Bihari Migrants after the COVID-19 Lockdown. http://www.mcrg.ac.in/RLS_Migration_2020/COVID-19.pdf.

Public Health Ontario. 2020. COVID-19 What we know so far. Social determinants of health. https:// www.publichealthontario.ca/-/media/documents/ncov/covid-wwksf/2020/05/what-we-know-socia 1-determinants-health.pdf?la=en.

Ramasubramanyam. 2020. https://theconversation.com/indias-treatment-of-muslims-and-migrants-putslives-at-risk-during-covid-19-136940. Accessed 23 Sept 2020.

Rodriguez, A. 2020. How does the coronavirus affect Africa's main migration routes? https://atalayar. com/en/content/how-does-coronavirus-affect-africas-main-migration-routes. Accessed 23 Sept 2020 .

Sachs, J. 2020. How inequality fuels COVID-19 deaths. Project Syndicate. https://www.project-syndi cate.org/commentary/inequality-fuels-covid 19-mortality-by-jeffrey-d-sachs-2020-06?barri er=accesspaylog. Accessed 23 Sept 2020.

Samaddar, R. 2016. Migrants and the neo-liberal city http://www.mcrg.ac.in/Rural_Migrants/Ranabir_ Samaddar.pdf. Accessed 23 Sept 2020.

SciDev.Net. 2020. COVID-19 gets to India's villages via migrant workers. https://medicalxpress.com/ news/2020-07-covid-india-villages-migrant-workers.html. Accessed 29 August 2020. 
Sen, S. 1992. Women Workers in the Bengal Jute Industry, 1890-1940: Migration, Motherhood and Militancy. Ph.D. thesis, University of Cambridge.

Shanthi, K. 2006. Female Labour Migration in India: Insights from NSSO Data. Working Paper 4/2006, Madras School of Economics, Chennai.

Shreedharan, S. and J. Jose. 2020. Support for India's migrants during COVID-19: navigating potential gaps in the system. https://www.centerforfinancialinclusion.org/support-for-indias-migrants-durin g-covid-19-navigating-potential-gaps-in-the-system. Accessed 23 Sept 2020.

Sinha, S. 2020. https://scroll.in/article/961181/covid-19-how-india-can-ensure-that-women-in-the-infor mal-sector-get-the-protection-they-deserve. Accessed 23 Sept 2020.

Sivaram, S. 2020. Is the Inter-State Migrant Workmen Act 1979, a dead letter? https://www.orfonline.org/ expert-speak/inter-state-migrant-workmen-act-1979-dead-letter-64979/.

Solinski, T. 2012. NREGA and labour migration in India: Is village life what the 'rural' poor want? The South Asianist 1 (1): 17-30.

Solomon, M.K., and S. Sheldon. 2018. The global compact for migration. International Journal of Refugee Law 30 (4): 584-590. https://doi.org/10.1093/ijrl/eey065.

Sood, A. and Nath, P. 2020. Innocuous mistakes or sleight of hand? Labour law changes. Economic and Political Weekly 55(22), 30 May. https://www.epw.in/journal/2020/22/insight/labour-law-chang es.html.

Sorkar, M.N.I. 2020. COVID-19 pandemic profoundly affects Bangladeshi workers abroad with consequences for origin communities. https://www.migrationpolicy.org/article/covid-19-pandemic-profo undly-affects-bangladeshi-workers-abroad-consequences-origin. Accessed 17 August 2020.

Srivastava, R. 2020a. Understanding circular migration in India. Its nature and dimensions, the crisis under lockdown and the response of the state. IIHD Centre for Employment Studies Working Paper 04/2020. https://www.ihdindia.org/Working\%20Ppaers/2020/IHD-CES_WP_04_2020.pdf. Accessed 16 August 2020.

Srivastava, R. 2020b. Vulnerable Internal Migrants in India and Portability of Social Security and Entitlements. Centre for Employment Studies Working Paper Series. WP02/2020, Institute for Human Development, New Delhi.

Srivastava, R., and R. Sutradhar, 2016. Migrating Out of Poverty? A study of migrant construction sector workers in India. http://www.ihdindia.org/1.pdf.

Subramaniam, R.R. 2018. Chai migrants: For decades, this region in Rajasthan has been providing Mumbai its tea sellers, Cityscapes, https://scroll.in/magazine/887831/chai-migrants-for-decades-thisregion-in-rajasthan-has-been-providing-mumbai-its-tea-sellers.

SWAN, Stranded Workers Action Network. 2020a. COVID-19 Lockdown, Migrant Workers, and the Inadequacy of Welfare Measures in India, April 2020.

SWAN. 2020b. https://covid19socialsecurity.files.wordpress.com/2020/05/32-days-and-counting_swan. pdf.

SWAN. 2020c. http://strandedworkers.in/wp-content/uploads/2020/06/SWAN-Report05062020-1.pdf.

The Globe and Mail. 29 July 2020. 83\% of COVID-19 cases in Toronto among racialized people from May-July, data suggest. https://www.theglobeandmail.com/canada/article-torontos-marginalizedcommunities-disproportionately-affected-by/.

The Economic Times. 2020. Amid lockdown, migrant workers a content lot in Kerala. https://economicti mes.indiatimes.com/news/politics-and-nation/amid-lockdown-migrant-workers-a-content-lot-inkerala/articleshow/75243908.cms?from $=$ mdr. Accessed 30 August 2020).

The Indian Express. 2020. Odisha announces Rs 17,000 crore package to create jobs for migrants who returned home. https://www.newindianexpress.com/states/odisha/2020/may/29/odisha-announcesrs-17000-crore-package-to-create-jobs-for-migrants-who-returned-home-2149627.html. Accessed 30 August 2020).

The Week. 2020. Kerala sets an example for rest of India with its exceptional treatment of "guest workers". https://www.theweek.in/news/india/2020/04/20/kerala-sets-an-example-for-rest-of-india -with-its-exceptional-treatment-of-guest-workers.html. Accessed 30 August 2020.

The Wire, 30 June 2020. https://thewire.in/government/modi-speech-china-free-ration-garib-kalya n-november Accessed 16 August 2020.

Thomas, C., and N. Jayaram. 2020. Pandemic Crisis: "migrant home-based women workers work 8 Hours/Day For Rs 10-15. https://www.indiaspend.com/pandemic-crisis-migrant-home-based -women-workers-work-8-hours-day-for-rs-10-15/.

UNICEF. 2020. Returning home isn't an option. https://www.unicef.org/coronavirus/niger-returninghome-isnt-option. Accessed 21 August 2020. 
United Nations, Human Rights Office of the High Commissioner. 2020. COVID-19 and the human rights of migrants: guidance. https://www.ohchr.org/Documents/Issues/Migration/OHCHRGuidance COVID19_Migrants.pdf. Accessed 24 August 2020.

UNHCR. undated. Migration and development: a human right approach. https://www.unhcr.org/enie/4bf644bd9.pdf.

UN. 2020a. https://www.un.org/sites/un2.un.org/files/sg_policy_brief_on_people_on_the_move.pdf.

WIEGO. 2020. Informal workers in the COVID-19 crisis: A global picture of sudden impact and longterm risk. https://www.wiego.org/resources/informal-workers-covid-19-crisis-global-picture-sudde n-impact-and-long-term-risk. Accessed 24 August 2020.

World Bank. 2015. Leveraging urbanization in India. https://www.worldbank.org/en/country/india/brief/ leveraging-urbanization-india. Accessed 24 August 2020.

World Bank. 2020a. https://openknowledge.worldbank.org/handle/10986/33634.

World Bank. 2020b. COVID-19 crisis through a migration lens. Migration and Development Brief No. 32, World Bank, Washington, DC. https://openknowledge.worldbank.org/handle/10986/33634. Accessed 19 August 2020.

Yang, A. 1989. The Limited Raj: Agrarian Relations in Colonial India. Saran District 1793-1920. Delhi: Oxford University Press.

Publisher's Note Springer Nature remains neutral with regard to jurisdictional claims in published maps and institutional affiliations. 